\title{
Formulating Environmentally Friendly Oil- Base Mud using Jatropha Oil
}

\author{
Taher El Fakharany ${ }^{1,2}$, Roshdy Khaled ${ }^{2}$, Amr Mahmoud ${ }^{2}$ \\ Mining and Petroleum Engineering Department, Faculty of Engineering, Al-Azhar University, Cairo, Egypt ${ }^{1}$ \\ Petroleum and Energy Engineering Department, the American University in Cairo (AUC) ${ }^{2}$
}

\begin{abstract}
In recent years, restrictions have been established in many areas of the world against the most dominant oil base mud; (diesel). These restrictions came about as a result of the detrimental environmental impact occurring from the use of this drilling fluid. Hence a worldwide trend was brought about, disregarding the use of this mud in drilling operations onshore and significantly offshore where the environmental impact was higher. Oil base mud now faces restrictions of recently passed legislations that require specific disposal methods that are regarded extremely costly. This is forcing the industry to shift away from its use as it is becoming less feasible to operate with. Hence, the need for an integrated alternative solution to oil base mud that will pass the recent environmental regulations thus removing disposal costs and lowering the overall toxicity. Of these solutions, biodegradable oils, particularly vegetable oils have been the focus of many recent researchers. The selection of these oils is based on their low costs of obtaining these oils and concurrently having similar properties of oil base mud. Jatropha oil base mud shows high potentialdue to its abundance worldwide. The laboratory data indicate that Jatropha oil base mud has a more ideal yield point value than diesel base mud, theprepared jatropha base mud will perform the same function as dieselbase mud, but more efficiently with less frictional pressure losses. The experimental work carried out showed high potential of jatropha oil base in comparison to oil base in both physiochemical and rheological properties as an oil and drilling fluid, better thermal stability in HPHT wells, safe due to its fire capacity resistance. Finally jatropha is less expensive than oil base mud with less environmental impact and can be applied in the industry.
\end{abstract}

Keywords: Jatropha Oil, Oil- Base Mud, diesel, drilling fluid, biodegradable oils, toxicity.

\section{INTRODUCTION}

One of the most important factors of drilling operations is the drilling mud. This is partly due to the critical task of the mud performs in removing drilling cuttings and preserving and supporting the wellbore [1].Water, chemicals, oils and clay make up drilling mud as we use it today. To benefit from a successful drilling job one must account for many elements to formulate a competent drilling mud. The most important of these elements is the muds physical and rheological properties that should be carefully calibrated and measured in relation to the formation lithology and its pressure.

Another critical element to be considered is to ensure the drilling fluids meet the environmental regulations enforced. One of the most important elements of choosing a competent drilling mud is to lower costs. For example, by enhancing the costly oil base mud it will alternatively lower the overall cost [2]. The mud engineer is usually in charge of selecting the best range of characteristics such as viscosity, compositions ratio and density [3]. With the development of drilling technologies and methods of drilling such as deviated wells, deep water wells and high temperature/pressure wells a matching drilling mud approach must be selected to ensure a successful function. Types of mud, cost, performance and its environmental impacts are some of the considerations that must be looked at. An alternative to drilling fluids is not currently available in the near future; however a more ideal efficiency could be reached with methods of enhancement that the drilling fluids have gone through since their inception.

Drilling mud is typically categorized into 3 types: oil based muds, water based muds and air based muds. Oil base mud is considered more favorable in specific scenarios and formations such as deep water, high pressure high temperature wells [4]. However the use of oil base mud causes a significant impact on the environment which results in strict regulations of its use and added disposal costs elevating its cost significantly [5]. In marine environments regulations are stricter due to the large impact the disposal of oil base mud cuttings can cause to the surrounding marine environment and its inhabitants [6]. Cuttings must be put under significant processing before they can actually be disposed of [7]. Disposal methods are numerous such as thermal desorption and more popularly landfills. However these methods are inefficient and very expensive to operate with making them unfavorable to the industry.

\section{LITERATRURE REVIEW \&PROBLEM OF STATEMENT}

The problems at stake can be divided into three critical points: Regulations and legislations, cost and increasing unconventional reservoirs. These are pushing the industry 
Vol. 4, Issue 1, January 2017

to formulate a drilling fluid that can conform to these conditions and excel where the current oil base mud has failed [8]. In recent years many legislations and restrictions enforced have made diesel unfavorable to work with throughout the drilling process [5]. An integrated solution to this problem is needed using systematic and quantitative studies to come up with an applicable drilling fluid. This solution must cover aspects of performance and cost in order to be truly sufficient to use. Over the past few years a direction of focus went to formulating a biodegradable oil base mud. This mud initially would cause a much lower impact on the environment leading to a reduction in cost via disposal costs and simultaneously have the same favorable properties as current oil base muds. The results of these paper will be a proposals to replace current oils used in drilling operations with vegetable oils. With many research studies done on the use of vegetable oils in many industrial applications, even current applications of using it as fuel [9], it was expected that it's environmentally friendly properties grabbed the attention of the petroleum industry facing regulations and public scrutiny across the world. Of these impacts caused to the environment is that of toxic oil base muds in offshore activities [6]. If a shift was made to replace the current Oil base mud with a less harmful substitute, many costs, regulations and public concerns would be resolved.

With a vast variety of vegetable oils, a selection must be made to utilize the most suitable oil. The selection criterion that was approached in this paper started with worldwide production of the oil. Palm oil came first, followed by soybean oil which are both significantly higher in production than the rest combined. However previous studies have been done on the use of palm oil as a substitute to current Oil base mud, [2]. While the results formulated a mud sample that had favorable rheological properties, the muds density and $\mathrm{pH}$ values were much lower than average which is a downfall that cannot be overlooked. We selected the next biggest vegetable oil in production, Jatropha oil. Jatropha oil is popular because it is cheap, healthy and can be utilized in several industries. Jatropha oil is free from trans-fats and contains low amounts of saturated fats [10].

This indicates in the case of Jatropha oil showing favorable properties as a suitable substitute to diesel, availability would have no impact on the oil and gas industry. The cost ofJatropha oil, internationally a barrel of Jatropha oil costs roughly $\$ 0.64$ / literwhich is similar to the cost of diesel making it an insignificant factor in our comparison.

The jatropha plant has been the focus of many studies in Egypt in recent years due to its ability to grow in poor, dry and inhospitable conditions. Its potential is largely due to its high oil content, adaptability, drought-resistant properties and low nutrition requirements for growth. An appealing aspect of the jatropha plant is its ability to grow with the use of wastewater. The nitrogen and chemicals in wastewater serve as nutrition to the plant. Concurrently wastewater disposal is a large issue in Egypt which could be turned into a resource for large scale plantation of the jatropha plant [11]. Jatropha has the potential to pass all aspects of our selection criteria affecting both economy and environment. Furthermore it will not affect current agricultural lands as it can grow on inhospitable lands in which other plants cannot.Referring to the Egyptian code for wastewater treatment, certain crops can be irrigated using wastewater provided they are not food crops. The code contains three levels of wastewater, A, B and C, (A being the highest treated and $\mathrm{C}$ the lowest), with a list of crops that can be used for each grade. Adding to the benefits of jatropha, it falls under $\mathrm{C}$ grade wastewater to be irrigated, requiring minimal processing.Jatropha is more suitable to be grown in hotter areas of Egypt to the south, closer to the equator. This is due to the favorable results of very high oil content in these areas[12]. The details of the cost are shown in the Table (1) that shows that the use of jatropha oil becomes feasible in the fourth year where the price of one liter drops against the price of diesel oil.

The workin this paper can be summarized into four clear steps:

Collection of materials (diesel oil, jatropha oil)

Comparison between the physicochemical properties of diesel oil and jatropha oil

Formulation of the new drilling fluid

Rheological comparison between the two mud samples

\section{MATERIAL SELECTION AND EXPERMENTAL WORK}

We obtained four liters of diesel oil from a regular petrol station at $1.6 \mathrm{LE} / \mathrm{liter}$. This price however is the subsidized price available to the public, not the price at which the companies get their diesel being the international price of $\$ 0.77 /$ liter. The next material collected wasjatropha seeds, the process of acquisition of jatropha seeds is a simple process. The first step being the shelling stage is where seeds outer coat are removed. Oil is then extracted through a mechanical process of crushing. Followed by the filtering of the oil to make sure no impurities are present. We obtained 50 kilograms of jatropha seeds from a trader in Qalyubia. The seeds were crushed giving a yield of $37 \%$ and 18.5 kilograms of jatropha oil. Knowing the density of jatropha oil being $0.932 \mathrm{~kg} /$ liter gave us roughly 19.8 liters of jatropha oil.

\section{Physochemial properies :}

The next step was testing the physicochemical properties, which provided an early sign of desirability of the formulated mud base on favorable criteria. The four properties selected to compare were density, plastic viscosity, pour point and flash point, all are measured in the PVT lab.

\section{Results of the physiochemical properties :}

1) Density: Results showed that the vegetable oil's densities were significantly higher than diesel oil. However a benefit of the higher densities of jatropha are 
Vol. 4, Issue 1, January 2017

that less barite could be used, saving on the cost of formulation.

2) Plastic viscosity of the vegetable oils showed a much higher viscosity than diesel oil. To account for this, the use of viscosity modifiers and reducers must be used. That being said, treating an oil for high viscosity is more favorable than treating a low viscosity oil. This is due to the favorable properties highly viscous oils contain, acting as a water base mud without being water wet and therefore unable to perform in necessary extreme conditions. This results in the need to repeat formulation steps to acquire the correct oil/water and viscosity modifier ratios.

3) Pour point: jatropha showed a higher pour point, this advises that it should not be used in cold environments. Since the jatropha is more suitable in Egypt, with a hot and relatively stable climate.

4) Flash point: jatropha showed a high flash and fire temperatures, which have proven difficult to achieve in a university lab. Results of the four parameters are shown in Table (2):

\section{Mud Formulation and Rheological properties :}

By formulating a sample of drilling mud from each type and testing its rheological properties as criteria to select the most suitable and advanced drilling mud in order to be chosen finally as a suitable replacement.

\section{Mud Density}

After preparing a mud sample with different amounts of barite, to determine the influence of the barite on the mud sample in order to reach the ideal density that is used in the oil industry. The density of the 10 gram barite was the most reliable comparing to most drilling operations having a density of mud of approximately $8 \mathrm{lb} / \mathrm{gal}$, and the effect of barite on jatropha based mud samples are illustrated in Table (3).

\section{FAN V-G Viscometer Rheological Properties}

The rheological results of the diesel base mud and jatropha are illustrated in Table (4).

\section{Mud Filtration Test}

The mud filtration test is used to determine the mud cake thickness of each mud. It is done using the standard API filter press by applying differential pressure. The pressure applied in our university laboratory was $100 \mathrm{psi}$ and the mud cup was attached to the pressure valve and left for 30 minutes, while collecting the filtrate within the 30 minutes. The filtrate results of the jatropha base mud yielded are more favorable than oil base mud, shown in Table (5).The jatropha base mud had the lowest mud cake thickness.

\section{PH Results}

The sample without NAOH (PH enhancer) wasn't available. Therefore, the $\mathrm{PH}$ measurement was only measured for the best mud sample, $\mathrm{PH}$ value of jatropha oil based mud $=9.5$

\section{Diesel Base Mud}

After preparing many samples, ideal quantities were reached, shown in Table (6).After shutting off the mixer the mud was ready to use, and the drilling fluid partially homogenous. All the mud components had to be blended together.

\section{Jatropha Oil Base Mud}

The target here was formulating drilling fluid with superior rheological properties than diesel.

The preparation of the jatropha base mud went very smooth. The physicochemical properties of the jatropha oil were more suitable, especially the viscosity of jatropha oil being the same rheological values of diesel base mud. The main obstacle faced in preparation of the jatropha base mud was that the oil wasn't mixing well with the water. Therefore, we started to decrease the quantity of the water added and increase the emulsifiers used. Adding a larger quantity of emulsifiers helped the water and the oil to mix; forming homogenous stable emulsion, portrays the quantities and order of formulation. The Jatropha mud composition are shown inTable (7), that can perform and act exactly like diesel base mud with all the superior rheological features of diesel mud. Certain factors are adjusted to obtain the most suitable results:

\section{Adding viscosity reducer EMEC-WET \\ Dividing the amount of the emulsifiers added into two stages; after oil and water \\ - Changing the filter loss agent from starch to soda ash}

Adding the emulsifiers in two stages helped in dispersing the water in oil, as the oil is the continuous phase and the emulsion was obtained rapidly and more stably.

\section{DISCUSSION OF THE RESULTS}

- When comparing jatropha with diesel oil base mud, jatropha density is partially higher than diesel. This provides the advantage of higher density, leading to applicability of carrying drilled cuttings. Another advantage of jatropha base mud is its greater ability to increase its weight. As the results showed, jatropha base mud increased from $8.0 \mathrm{lb} /$ gallon to $10.5 \mathrm{lb} /$ gallon by adding only 5 gram of barite which is a $18 \%$ increase. Meanwhile, diesel only increased by $6 \%$ by applying the same amount of barite to the sample.

- Jatropha oil base mud, yielded appealing results, proving its potential to replace diesel base mud. Jatropha oil base mud has a more ideal yield point value than diesel base mud. A drawback of diesel base mud is its high yield point which leads to high pressure losses. The prepared jatropha base mud will perform the same function as diesel, but more efficiently with less frictional pressure losses. In addition to this, jatropha base mud has a plastic viscosity of $14 \mathrm{cp}$, while diesel base mud is $16 \mathrm{cp}$. It is not a drastic difference, but the lower the plastic viscosity the less resistance to flow. If jatropha base mud is used in drilling operations it may require less circulation pressure. Lower circulation pressure will lead to lower pumping costs and 
Vol. 4, Issue 1, January 2017

reduce the chances of losing circulation during operation. The gel strength is also a vital parameter in evaluating the drilling fluid performance. There isn't a large difference between the gel strength of jatropha and the diesel oil, they both have a good gel structure. These rheological results showed that jatropha has strong potential to replace diesel. - The filtration results showed that jatropha base mud collected less water and oil volume as filtrate. Diesel oil base mud follows with higher filtrate volumes .Higher oil and water filtrate volumes indicate that the drilling fluid failed to achieve stable emulsion between the oil and water. Therefore, jatropha oil based mud is considered to be a better alternative than the diesel base mud by achieving stronger emulsion between the oil and water. In Table (6), jatropha base mud showed higher performance than diesel base mud, as the measured mud cake thickness was only 2 $\mathrm{mm}$. However, the diesel base mud sample generated $3 \mathrm{~mm}$ mud cake thickness and was more porous.

- It is clear that diesel oil is much more toxic than biodegradable oils, it is important to illustrate the toxicity level of each drilling fluid. The test was performed by getting three bean plants and planted them in each of their soils amount of the prepared mud samples. We left the plants for a calculated amount of time and noted how long they survived. The plant where diesel base mud was immersed inside its soil survived for 2 days. While, the plants with jatropha mud survived for weeks. This provides evidence of the non-biodegradability of diesel and its toxicity of its aromatic content.

\section{CONCULSIONS AND RECOMMENDATION}

The oil and gas industry is being weighed down by laws and regulations regarding toxic oil base-drilling fluid and its impact on the environment. This accompanied by disposal costs is forcing the industry to search for applicable substitutes to the currently used oil base mud and Jatropha oil are presented as potential candidates to make this transition. The experimental work showed that high potential of jatropha oil base mud in comparison to oil base mud in both physiochemical and rheological properties as an oil and drilling fluid. Toxicity tests again gave positive results regarding vegetable oils, freeing them of the newly imposed regulations. Jatropha oil base has better thermal stability in HPHT wells, more safe due to its fire capacity resistance, less filter loss\& mud cake thickness and better density than oil base mud.
The overall comparison showed jatropha oil can be applicable as a substitute to oil base mud.

Further studies need to be conducted locally on farming this plant for its oil on a large-scale in order to be used efficiently in many other industries than the proposed, environmentally-friendly oil base drilling fluid.

\section{REFERENCES}

[1] Amanullah, M. 2005. Physio-Chemical Characterisation of Vegetable OIls and Preliminary Test Results of Vegetable-OilBased Muds. Presented at the SPE/IADC Middle East Drilling Technology Conference and Exhibition, Dubai, United Arab Emirates. SPE-97008

[2] Dosunmu, A. 2010.Development of Environmentally Friendly Oil Based Mud using Palm-Oil and Groundnut-Oil. Presented at the 34th Annual SPE International Conference and Exhibition, Calabar, Nigeria, 31 July-7 August. SPE-140720

[3] Bland, R. G., Mullen, G. A., Gonzalez, Y. N., Harvey, F. E., \& Pless, M. L. (2006, January 1). HPHT Drilling Fluid Challenges. Society of Petroleum Engineers. doi:10.2118/103731-MS

[4] Ewy, R. T., \& Morton, E. K. (2008, January 1). Wellbore Stability Performance of Water Base Mud Additives. Society of Petroleum Engineers. doi:10.2118/116139-MS

[5] Cripps, S.J., Picken, G., Aabel, J.P., Andersen, O.K., Heyworth, C., Jakobsen, M., Kristiansen, R., Marken, C., Paulsen, J.E., Shaw, D., Annand, A., Jacobsen, T.G. and Henriksen, I.B. 1998.Disposal of oil-based cuttings. The Norwegian Oil Industry Association (OLF) 3, p. 1-145

[6] Gbadebo, A.M., Taiwo, A.M and Eghele, U.. (2010). Environmental Aspect of Oil and Water-Based Drilling Muds and cuttings from Dibi and Ewan offshore wells, Niger delta, Nigeria.African Journal of Environmental Science and Technology. 4(5):284-292.

[7] Hussein, A.M.O. and Amin, R.A.M. 2010. Density Measurement of Vegetable and Mineral Based Oil Used in Drilling Fluids. Presented at the 34th Annual SPE International Conference and Exhibition, Calabar, Nigeria, 31 July-7 August

[8] Friedheim, J. E.1998. Area-specific analysis reflects impact of new generation fluid systems on deepwater exploration.IADC/SPE Asia Pacific Drilling Technology Conference,IADC. SPE-47842. DOI:10.2118/47824-MS.

[9] Lang, Andrew, and Hazir Farouk Abdelraheem Elhaj. "Jatropha Oil Production for Biodiesel and Other Products." (2013): n. pag. Web. 25 Dec. 2015.

[10] Agwu, O.E., Isemin, I.A., and Akpabio, M.G. 2015. Cost Benefit Analysis of Vegetable Oils Used As Alternatives to Diesel in the Formulation of Oil-Based Drilling Muds. Presented at the Nigeria Annual International Conference and Exhibition, Lagos, Nigeria, 4-6 August.SPE-178265.

[11] Soliman, W.M. and He, X.R. (2015) The Potentials of Jatropha Plantations in Egypt: A Review.Modern Economy, 6, 190-200.

[12] Barsoum, F. Bassiouny, M. Hussein, M. Othman, A.(2016). The Production of Biodiesel from Jatropha in Egypt.AUC.

Table 1: Comparison between the price of jatropha and oil base mud in the fourth year

\begin{tabular}{|l|l|l|l|l|l|l|}
\hline Year & $\begin{array}{l}\text { Fixed } \\
\text { Cost/Year }\end{array}$ & $\begin{array}{l}\text { Operating } \\
\text { Cost/Year }\end{array}$ & $\begin{array}{l}\text { Yield of } \\
\text { Jatropha/ Year }\end{array}$ & $\begin{array}{l}\text { Price of 1 litre of } \\
\text { Jatropha /year }\end{array}$ & $\begin{array}{l}\text { Price of 1 litre of } \\
\text { Diesel in EGP }\end{array}$ & Savings \\
\hline 1 & 772000 & $3,061,412$ & 111,070 & 34.51347799 & 13 & -21.5135 \\
\hline 2 & 772000 & $3,367,553$ & 222,139 & 18.6349673 & 13 & -5.63497 \\
\hline 3 & 772000 & $3,704,308$ & 333,209 & 13.43393486 & 13 & -0.43393 \\
\hline 4 & 772000 & $4,074,739$ & 444,278 & 10.90924826 & 13 & 2.090752 \\
\hline 5 & 772000 & $4,516,845$ & 666,417 & 7.936239622 & 13 & 5.06376 \\
\hline 6 & 772000 & $4,968,530$ & 888,556 & 6.460515713 & 13 & 6.539484 \\
\hline
\end{tabular}


International Advanced Research Journal in Science, Engineering and Technology

ISO 3297:2007 Certified

Vol. 4, Issue 1, January 2017

\begin{tabular}{|l|l|l|l|l|l|l|}
\hline 7 & 772000 & $5,465,383$ & 888,556 & 7.019684747 & 13 & 5.980315 \\
\hline 8 & 772000 & $6,011,920$ & 888,556 & 7.634769221 & 13 & 5.365231 \\
\hline 9 & 772000 & $6,613,112$ & 888,556 & 8.311363606 & 13 & 4.688636 \\
\hline 10 & 772000 & $7,274,423$ & 888,556 & 9.055617204 & 13 & 3.944383 \\
\hline
\end{tabular}

Table 2: physicochemical properties results

\begin{tabular}{|c|c|c|c|c|c|c|}
\hline Property & $\begin{array}{l}\text { Density } \\
(\mathrm{kg} / \mathrm{m} 3)\end{array}$ & Pour Point ${ }^{\circ} \mathrm{C}$ & $\begin{array}{l}\text { Flash } \\
\text { Point }{ }^{\circ} \mathrm{C}\end{array}$ & $\begin{array}{l}\text { Fire } \\
\text { Point }{ }^{\circ} \mathrm{C}\end{array}$ & $\begin{array}{l}\text { Kinematic } \\
\text { Viscosity @ } 40^{\circ} \mathrm{C}\end{array}$ & $\begin{array}{l}\text { Aromatic } \\
\text { Content (\%) }\end{array}$ \\
\hline $\begin{array}{l}\text { Base Oil Required } \\
\text { Properties }\end{array}$ & N/A & $\begin{array}{l}<\text { Ambient } \\
\text { Temperature }\end{array}$ & $>66$ & $>80$ & $2.3-3.5$ & $4-8$ \\
\hline Diesel Oil & 830 & -18 & 66 & 108 & $2.7-3.4$ & $25 \% \mathrm{v} / \mathrm{v}$ \\
\hline Jatropha Oil & 933 & 7 & 210 & 235.2 & 52.76 & N/A \\
\hline
\end{tabular}

Table 3: Density of Diesel base mud and Jatropha base mud with different barite content

\begin{tabular}{|l|l|l|}
\hline Barite Content (grams) & Diesel Base Mud, Ib/gal & Jatropha., Ib/gal \\
5 & $\mathbf{7 . 3}$ & $\mathbf{8}$ \\
\hline 10 & $\mathbf{8 . 1 0}$ & $\mathbf{1 0 . 5}$ \\
\hline
\end{tabular}

Table 4:Rheological results of diesel base mud and Jatropha base mud

\begin{tabular}{|l|l|l|}
\hline Rheological Parameters & Jatropha base mud & Diesel base mud \\
Plastic viscosity & $14 \mathrm{cp}$ & $15 \mathrm{cp}$ \\
\hline Yield point & $10 \mathrm{lb} / 100 \mathrm{ft}^{2}$ & $16 \mathrm{lb} / 100 \mathrm{ft}^{2}$ \\
\hline Apparent viscosity & $19 \mathrm{cp}$ & $23 \mathrm{cp}$ \\
\hline Gel strength (10 seconds) & $6 \mathrm{lb} / 100 \mathrm{ft}^{2}$ & $7 \mathrm{lb} / 100 \mathrm{ft}^{2}$ \\
\hline Gel strength (10 minutes) & $7 \mathrm{lb} / 100 \mathrm{ft}^{2}$ & $9 \mathrm{lb} / 100 \mathrm{ft}^{2}$ \\
\hline
\end{tabular}

Table 5: Filtration results of diesel base mud andJatropha base mud

\begin{tabular}{|l|l|l|}
\hline Filtrate Properties & Jatropha base mud & Diesel base mud \\
Total fluid volume & $23 \mathrm{ml}$ & $30 \mathrm{ml}$ \\
\hline Oil volume & $8 \mathrm{ml}$ & $11 \mathrm{ml}$ \\
\hline Water volume & $15 \mathrm{ml}$ & $19 \mathrm{ml}$ \\
\hline Mud cake thickness & $2 \mathrm{~mm}$ & $3 \mathrm{~mm}$ \\
\hline
\end{tabular}

Table 6: Diesel base mud components

Mud Component
\begin{tabular}{|l|l|l|l|l|} 
Non-wetting Agent & Diesel Oil & $245 \mathrm{ML}$ & - & 1 \\
\hline Primary Emulsifier & EMEC PEMUL1000 & $6 \mathrm{ML}$ & 2 & 2 \\
\hline $\begin{array}{l}\text { Secondary } \\
\text { Emulsifier }\end{array}$ & EMEC-SEMUL100 & $4 \mathrm{ML}$ & 5 & 3 \\
\hline Filter Loss Agent & $\begin{array}{l}\text { Hydroxyl ethyl } \\
\text { cellulose }\end{array}$ & $0.35 \mathrm{~g}$ & 5 & 4 \\
\hline Wetting Phase & Water & $105 \mathrm{ML}$ & 16 & 5 \\
\hline Viscosifier & Bentonite & $25 \mathrm{~g}$ & 4 & 6 \\
\hline PH Enhancer & NAOH & $0.25 \mathrm{~g}$ & 5 & 7 \\
\hline Weighting Agent & Barite & $10 \mathrm{gram}$ & 8 & 8 \\
\hline
\end{tabular}


International Advanced Research Journal in Science, Engineering and Technology

ISO 3297:2007 Certified

Vol. 4, Issue 1, January 2017

Table 7: Composition of Jatropha base mud

\begin{tabular}{|l|l|l|l|l|}
\hline Mud Component & Component Name & $\begin{array}{l}\text { Component } \\
\text { Quantity }\end{array}$ & $\begin{array}{l}\text { Mixing Duration } \\
(\text { mins })\end{array}$ & Mixing Order \\
\hline Non-wetting Agent & Jatropha Oil & $200 \mathrm{ML}$ & - & 1 \\
\hline Primary Emulsifier & EMEC PEMUL1000 & $4 \mathrm{ML}$ & 2 & 2 \\
\hline Secondary Emulsifier & EMEC-SEMUL100 & $3 \mathrm{ML}$ & 5 & 3 \\
\hline Filter Loss Agent & Soda Ash & $0.35 \mathrm{~g}$ & 5 & 4 \\
\hline Filter Loss Agent & starch & $0.35 \mathrm{~g}$ & 5 & 3 \\
\hline Wetting Phase & Water & $90 \mathrm{ML}$ & 15 & 5 \\
\hline Primary Emulsifier & EMEC PEMUL 1000 & $4 \mathrm{ML}$ & 4 & 6 \\
\hline Secondary Emulsifier & EMEC SEMUL 100 & 3 & 4 & 7 \\
\hline Viscosifier & Bentonite & $20 \mathrm{~g}$ & 8 & 8 \\
\hline PH Enhancer & NAOH & $0.25 \mathrm{~g}$ & 3 & 9 \\
\hline Weighting Agent & Barite & $5 \mathrm{gram}$ & 10 & 10 \\
\hline Viscosity Reducer & EMEC WET & $6 \mathrm{ML}$ & 10 & 11 \\
\hline
\end{tabular}

